The oestrogen-dependent regulation of cell behaviour is realised by stimulation of specific oestrogen receptors. The classical oestrogen receptors ER $\alpha$ and ER $\beta$ are transcription factors, and they modulate expression of hormonally regulated genes, while the third one, GPER, is thought to be responsible for the observed rapid, non-genomic cellular response. Oestrogen dependency is attributed to a number of cancers, including breast, ovarian and endometrial cancer; however, there is still growing evidence that melanoma should also be cited as a hormonally dependent tumour. This comes from the observations of gender-related differences in melanoma progression and reports concerning the history of the malignant course of melanomas during pregnancy. Although, the observations of oestrogen regulation of melanoma progression are controversial, the effect of oestrogen should not be neglected, as the skin possesses its own hormonal microenvironment. This aspect of melanoma progression should be taken under careful consideration as it may offer new therapeutic possibilities.

Key words: melanoma, oestrogen, oestrogen receptor $\alpha$, oestrogen receptor $\beta$, GPER.

Contemp Oncol (Pozn) 2014; 18 (5): 302-306 DOI: $10.5114 /$ wo.2014.43938

\section{Is oestrogen an important player in melanoma progression?}

\author{
Marcelina E. Janik, Klaudyna Bełkot, Małgorzata Przybyło
}

Department of Glycoconjugate Biochemistry, Institute of Zoology, Jagiellonian University, Krakow, Poland

\section{Introduction}

The biological effects of oestrogen are mediated by its binding to, and activation of, the oestrogen receptors $E R \alpha$ and $E R \beta[1,2]$. The observed activation of the $G$ protein-coupled oestrogen receptor (GPER) after oestrogen stimulation implies that it could be the third oestrogen receptor [3-5]. ER $\alpha$ and $E R \beta$ are transcription factors interacting with the oestrogen response elements (ERES) located within the promoter regions of hormonally regulated genes (Fig. 1). They participate in the formation of a multi-protein complex there, and as a result, they regulate the transcription process [6-8]. Both these receptors possess multi-domain structures and are composed of a highly conserved DNA-binding domain, a ligand-binding domain and two transcriptional activation functions AF1 and AF2. The DNA-binding domain is involved in recognition and binding of DNA and is located in the centre of the receptor protein, while the ligand-binding domain, engaged in receptor-ligand interactions, is located in the $\mathrm{COOH}$ terminal. The $\mathrm{NH}_{2}$-terminal domain is the most variable domain regarding its sequence and length. This is also the region where the AF1 is located, while the AF2 is found in the $\mathrm{COOH}$ terminal. AF1 is constitutively activated and AF2 is hormone-dependent $[9,10]$. ER $\alpha$ and $E R \beta$ are soluble receptors that can shuttle between the cytoplasm and the nucleus, but they are found largely in the nucleus [11-13]. These receptors are products of distinct genes located on different chromosomes. Both types are synthesised in multiple splice variants; however, the biological activity of those variants has not been fully understood yet. For example, the shorter $\mathrm{ER} \alpha$ isoforms lacking the $\mathrm{NH}_{2}$-terminal AF-1, named $h E R \alpha-46$ and $h E R \alpha-36$, have been isolated from different cell lines [14] but not from tissues. Their role in regulation of oestrogen effects in vivo is still unknown, although they represent an interesting research tool in vitro because they are able to heterodimerise with the full-length $E R \alpha$, leading to inhibition of AF-1. It is also postulated that they can localise to plasma membrane, and therefore they can be responsible for the rapid non-genomic oestrogen effects [15-18]. The third possible oestrogen receptor, GPER, shows many of the expected characteristics of a membrane oestrogen receptor. According to study results suggesting the constitutive internalisation of plasma membrane GPER $[19,20]$, its localisation seems to be mostly intracellular [4, 21]. It belongs to the G protein-coupled receptor (GPCR) with seven transmembrane domains. Its activation leads to the generation of cyclic AMP (CAMP), and it is thought to be responsible for the rapid oestrogen-mediated activation of Src-dependent signalling pathway leading to extracellular signal-regulated kinases (ERKs) activation [22-25]. There are some results suggesting that this signalling pathway activation is an effect of GPCR crosstalk with epidermal growth factor receptor (EGFR) [26], insulin-like growth factor receptor (IGFR) [27] and $\alpha 5 \beta 1$ integrin [28] (Fig. 1). The potential role of insulin-like growth factor-1 (IGF-1) in the regulation of GPER expression was evaluated by de Marco et al. [29]. The GPER association with non-genomic oestrogen action has been postulated for more than 10 years, but it 


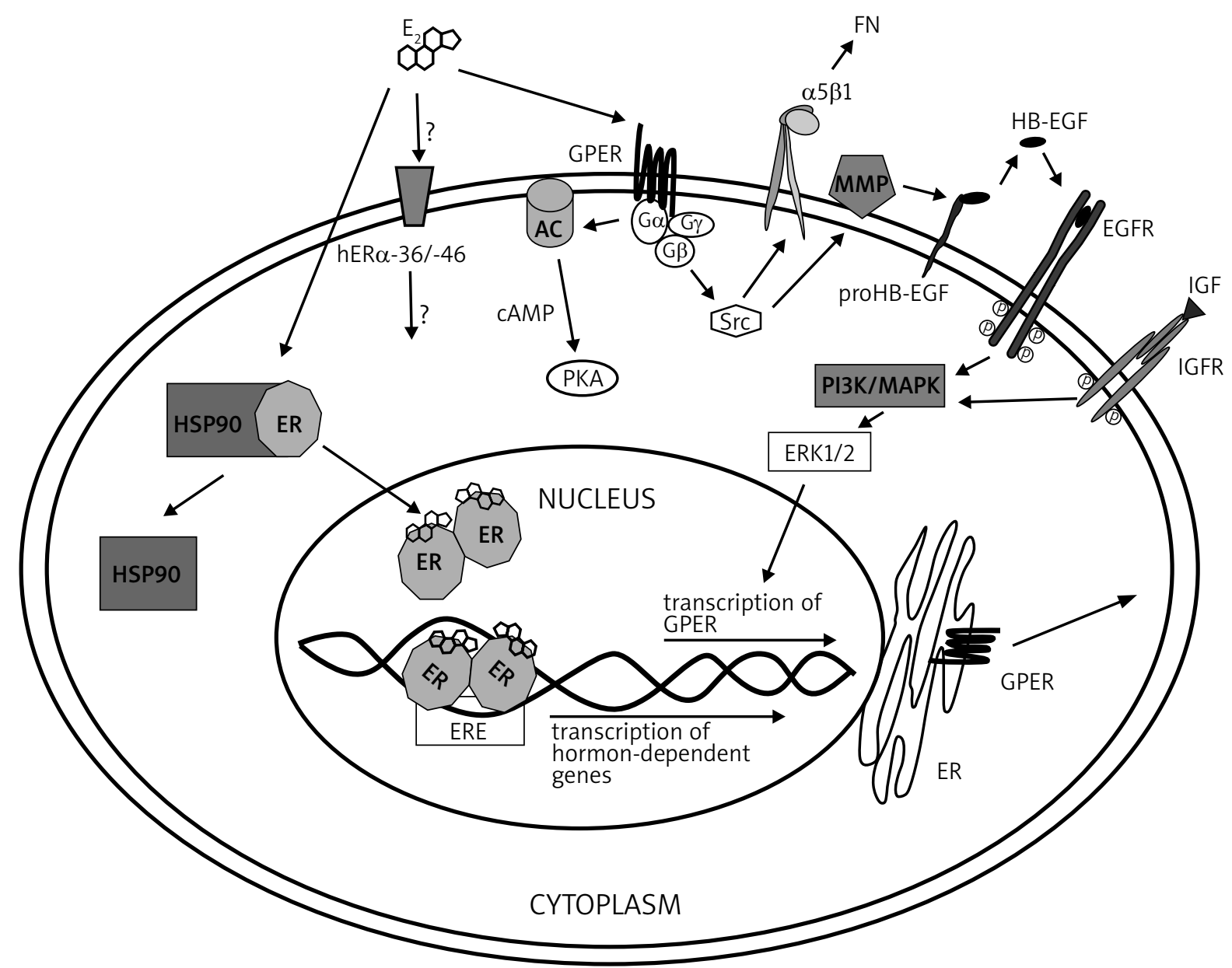

$\alpha 5 \beta 1$ - integrin receptor, AC - adenyl cyclase, EGFR - epidermal growth factor receptor, ER - endoplasmic reticulum, ER - oestrogen receptor ( $\alpha$ and $\beta$ ), ERE - oestrogen response element, ERK1/2 - extracellular signal-regulated kinases 1/2, FN - fibronectin, GPER - G protein-coupled oestrogen receptor, HB-EGF heparin-binding epidermal growth factor-like growth factor, HSP90 - heat shock protein 90, IGF - insulin-like growth factor, IGFR-insulin-like growth factor receptor, MAPK - mitogen-activated protein kinase, MMP - matrix metalloproteinase, PI3K - phosphoinositide 3-kinase, PKA - protein kinase A

Fig. 1. The mechanism of oestrogen action. The binding of E2 to the classical ER $\alpha$ or ER $\beta$ receptors leads to transcription of hormone-dependent genes. The third possible ER, GPER, is a membrane receptor, which is suggested to be responsible for non-genomic E2 action. Activated GPER triggers the clustering of $\alpha 5 \beta 1$ integrins, which in turn leads to the assembly of fibronectin matrix. Oestrogen action via GPER is enhanced by the presence of the IGFR-ligand complex, which results in stimulation of the GPER gene transcription. The GPER activation promotes also transactivation of EGFR, resulting in activation of signalling pathway, also leading to GPER gene transcription. Another possible way of E2 action is through $\mathrm{hER} \alpha-36 /-46$, which are shorter isoforms of ER $\alpha$ localised in plasma membrane. Their function is not yet fully understood

is still controversial, and there are still suggestions that it does not act as an oestrogen receptor at all [30]. However, the previously suggested hypothesis that GPER and ER act in concert in some signal transduction pathways has not been totally excluded [21].

\section{Oestrogen in melanoma progression}

Although it is commonly accepted that oestrogen regulates the growth and differentiation of normal and neoplastic tissues, including breast, ovarian and endometrial tumours [31], there is growing evidence of its influence on melanoma progression as well. There are case reports showing a poor prognosis for women in whom melanoma has developed during pregnancy [32, 33] and clinical observations demonstrating that women with melanoma have better prognosis than men [34]. There are also preclinical data showing that oestrogen and its metabolites may influence the course of melanoma progression [35, 36]. Nevertheless, observations of the influence of oestrogen on melanoma cells are controversial.

Melanomas originate from melanocytes, melanin-producing cells, found in the deep layer of the epidermis [37] and are considered as highly malignant tumours with an aggressive nature manifesting in the potential for early disease dissemination [38], which may come from very small tumour masses [39]. However, the formation of metastases in melanoma stage I and II is rarely observed. The early detection of neoplastic changes (in stage I and II) based on mole evaluation by $A B C D E$ criteria (Asymmetry in shape, Border irregularities, Colour heterogeneity, Diameter $>6 \mathrm{~mm}$ and Evolution [history of morphologic changes of the lesion] [40]) significantly improve the patient survival rate. Localised lesions in the early stages are usually curable by surgical resection. Increased lesion thickness and the pres- 
ence of metastases both in regional lymph nodes or distant tissues are poor prognostic indicators [41, 42]. A large number of risk factors that influence melanoma incidence and mortality rates have already been recognised. These factors are generally subdivided into two groups: genetic and environmental, which closely interact with each other [40, 42, 43].

An interesting aspect of melanoma progression, i.e. gender-related influence, has been addressed by many authors since the late 1960s [44]. Generally, it has been suggested that the disease develops more rapidly in men than in women, and that women have more favourable prognostic tumour characteristics than men [45-53]; however, geographical diversity in gender-related melanoma behaviour has also been observed [54]. There have also been studies analysing the presence of satellite and in-transit metastasis in male and female patients with cutaneous melanomas. For example, one of them, published by Meier et al. [39], showed the difference in frequencies of satellite and in-transit metastases between men (16.7\%) and women (26.4\%). Meier et al. [39] also observed that more frequently in men than in women the regional lymph nodes were the main sites of metastases. This observation was consistent with previous reports showing a stronger tendency in men towards tumour progression, from the stage of the primary tumour into the regional lymph nodes metastases [39]. Such gender-related tendencies in melanoma progression are thought to be influenced by endocrine status. Because skin has its own capacity to produce steroids, including oestrogen, its subjection to sex hormones should not be underestimated. Consequently, it was postulated by de Giorgi et al. [55] that melanomas should be at least cited among hormone-related neoplasms. These observations are also supported by analysis of oestrogen receptor (ER) expression in melanomas. It has been shown that ER expression is diverse between the tumour lesion and the healthy skin surrounding them. Moreover, a statistically significant difference in the mean oestrogen receptor (ER) concentrations in male versus female origin melanomas was found [56]. However, such reports are in contradiction with earlier studies indicating that the incidence of melanomas with detectable ER (refers to ER $\alpha$ - primarily discovered ER) is low, suggesting that the potential clinical usefulness of the ER assays in melanoma might be limited [57]. However, this was stated before the discovery of the second oestrogen receptor - ER $\beta$.

ER $\beta$ has been shown potentially to have a suppressive effect in a variety of human tumours, such as breast, prostate, colon and ovarian cancers [58]. ER $\beta$ is suggested to have a protective function against tumour formation because it reduces uncontrolled cell proliferation by increasing apoptotic activity $[34,59]$. Studies of melanoma cells have led to the conclusion that ER $\beta$ expression is altered in relation to the increasing depth of their invasion and to the diversified specificity of the tumour microenvironment [60]. These observations were further confirmed by de Giorgi et al. [61]. Based on the analysis of a small group of patients (14 patients, including 2 melanocytic nevi), they showed markedly decreased expression of ER $\beta$ in the metastatic phase of the melanoma. Moreover, it has been reported that melanoma tumours form patients suffering from lymph node metastases possessed lower expression of ER $\beta$ compared with surrounding normal skin [61]. Recently published results of a study of 66 patients with melanoma have also confirmed previous observations and have shown that increased Breslow thickness was inversely associated with lower ER $\beta$ expression in malignant melanoma tumours, compared to the adjacent healthy skin. In accordance with these findings, observations of gender-related metastasis formation have shown greater ER $\beta$ expression in women than men [62]. The reports of predominant expression of ER $\beta$ in melanoma cells have been independently confirmed by the immunohistochemistry analysis made by Ohata et al. [63], which revealed that melanocytes of melanocytic nevi and malignant melanoma cells express ER $\beta$ but not ER $\alpha$. Interestingly, it has been suggested by those authors that ER $\beta$ cannot be used as a marker of melanoma progression. Ohata et al. [63] ascertained that the intensity of staining for $E R \beta$, reflecting its level of expression, is not influenced by sex or by the serum levels of oestrogen, and it is very similar regardless of the age of female patients (ranging from 1 to 79 years) [63].

Some assumptions of the linkage between hormonal stimulation and ER expression in melanomas have been based on reports concerning melanoma development during pregnancy. In 1998 Grin et al. [64] published their critical review gathering information on controlled clinical trials assessing the effect of pregnancy on the prognosis of melanomas, and epidemiological data evaluating the risk of melanoma after exposure to oral contraceptives and hormonal replacement therapy. They concluded that pregnancy before, during or after the diagnosis of melanoma did not appear to influence 5-year survival rates. In their opinion, exposure to oral contraceptives and hormonal replacement therapy also did not appear to increase the risk of melanoma [64] as was observed in the case of other hormone-dependent cancers such as breast, ovarian, endometrial or prostate [65]. Since 1998, several reports revealing significant decreases in ER $\beta$ immunoreactivity in congenital nevi, in comparison to normal tissue and dysplastic nevi from pregnant women, have been published. All of them have suggested that nevi possess the capacity to be oestrogen-responsive. It was concluded that pregnancy and degree of atypia were associated with enhanced ER $\beta$ expression, with the exception of congenital nevi, in which the expression lowered [66]. Parallel observations have been made by Nading et al. [67] in the case of a young woman with large congenital nevi. Biopsy sample showed a decrease in nuclear staining for ER $\beta$. It has been postulated that ER $\beta$ may have a suppressant effect in melanomas [67]. The use of oral contraceptives and hormonal replacement therapy and their association with the Breslow thickness of cutaneous melanomas has also been continuously analysed since the publication by Grin et al. [64]. Koomen et al. [68] showed that there is no such statistically significant association; however, decreased Breslow thickness among women using oestrogen, especially among older women, has not been excluded [68]. The results of Tang et al. [69] also failed to support the role of menopausal hormone therapy in the development 
of non-melanoma skin cancer or melanomas in postmenopausal women. Nevertheless, ER $\beta$ was suggested as a useful prognostic marker for neoplasia and prognosis in cutaneous malignant melanoma.

\section{Summary}

In conclusion, it should be taken into consideration that, despite the fact that there is a great deal of contradiction in the results concerning the role of oestrogen in the course of melanomas, there is still growing clinical and preclinical evidence suggesting that oestrogen stimulation does have an influence on melanoma cells and may regulate their metastatic progression. Some new aspects of this problem are still being addressed by a number of researchers. Gathering those results will give a new picture of melanoma cell susceptibility to microenvironment agents. It is well known that melanomas represent an important public health problem in terms of morbidity and mortality. Therefore, efforts should be undertaken aimed at both primary prevention (risk reduction) and secondary prevention (early detection, which is critical to improve the clinical outcome of this disease) [70]. The growing focus on the role of oestrogen in melanoma progression is associated with the fact that there are still no effective and satisfying treatments for melanoma tumours. Despite the large number of agents studied in advanced melanoma [71-73], the therapy standards have remained almost unchanged and outcomes continue to be poor [74, 75]. For this reason, looking for new aspects of melanoma cell progression may serve as a starting point for finding novel methods of treatment.

The authors declare no conflict of interest.

This work was supported by grants from the Jagiellonian University, Krakow (in part by DS/MND/WBiNoZ/IZ/4/2012 and in part by WRBW/BiNoZ/IZ/3/2010).

\section{References}

1. Mosselman S, Polman J, Dijkema R. ER beta: identification and characterization of a novel human estrogen receptor. FEBS Lett 1996; 392: 49-53.

2. Shao W, Brown M. Advances in estrogen receptor biology: prospects for improvements in targeted breast cancer therapy. Breast Cancer Res 2004; 6: 39-52.

3. Maggiolini M, Picard D. The unfolding stories of GPR30, a new membrane-bound estrogen receptor. J Endocrinol 2010; 204: 10514.

4. Revankar CM, Cimino DF, Sklar LA, Arterburn JB, Prossnitz ER. A transmembrane intracellular estrogen receptor mediates rapid cell signaling. Science 2005; 307: 1625-30.

5. Bartella V, De Marco P, Malaguarnera R, Belfiore A, Maggiolini M. New advances on the functional cross-talk between insulin-like growth factor-I and estrogen signaling in cancer. Cell Signal 2012; 24: 1515-21.

6. Prossnitz ER, Sklar LA, Oprea TI, Arterburn JB. GPR30: a novel therapeutic target in estrogen-related disease. Trends Pharmacol Sci 2008; 29: 116-23.

7. Litwiniuk $M$, Bręborowicz J. Estrogen receptor $\beta$ in breast cancer. Wspolczesna Onkol 2004; 8: 478-482

8. Piekarski J. Estrogen and progesterone receptors in breast cancer - the current state of knowledge. Wspolczesna Onkol 2005; 9 : 371-379.
9. Webb P, Nguyen P, Shinsako J, et al. Estrogen receptor activation function 1 works by binding p160 coactivator proteins. Mol Endocrinol 1998; 12: 1605-18.

10. Heldring N, Pike A, Andersson S, et al. Estrogen receptors: how do they signal and what are their targets. Physiol Rev 2007; 87: 905-31.

11. Edwards DP. Regulation of signal transduction pathways by estrogen and progesterone. Annu Rev Physiol 2005; 67: 335-76.

12. Kocanova S, Mazaheri M, Caze-Subra S, Bystricky K. Ligands specify estrogen receptor alpha nuclear localization and degradation. BMC Cell Biol 2010; 11: 98.

13. Dębska S, Potemski P. Structure and function of hormone receptors and their crosstalk with growth factor receptors. Wspolczesna Onkol 2010; 14: 347-354.

14. Flouriot G, Brand H, Denger S, Metivier R, Kos M, Reid G, Sonntag-Buck V, Gannon F. Identification of a new isoform of the human estrogen receptor-alpha (hER-alpha) that is encoded by distinct transcripts and that is able to repress hER-alpha activation function 1. EMBO J 2000; 19: 4688-700.

15. Li Y, Lambert MH, Xu HE. Activation of nuclear receptors: a perspective from structural genomics. Structure 2003; 11: 741-6.

16. Wang Z, Zhang X, Shen P, Loggie BW, Chang Y, Deuel TF. Identification, cloning, and expression of human estrogen receptor-alpha36, a novel variant of human estrogen receptor-alpha66. Biochem Biophys Res Commun 2005; 336: 1023-7.

17. Lee LM, Cao J, Deng H, Chen P, Gatalica Z, Wang ZY. ER-alpha36, a novel variant of ER-alpha, is expressed in ER-positive and -negative human breast carcinomas. Anticancer Res 2008; 28 (1B): 479-83.

18. Rao J, Jiang X, Wang Y, Chen B. Advances in the understanding of the structure and function of ER- $\alpha 36$, a novel variant of human estrogen receptor-alpha. J Steroid Biochem Mol Biol 2011; 127: 231-7.

19. Sandén C, Broselid S, Cornmark L, Andersson K, Daszkiewicz-Nilsson J, Mårtensson UE, Olde B, Leeb-Lundberg LM. G protein-coupled estrogen receptor $1 / G$ protein-coupled receptor 30 localizes in the plasma membrane and traffics intracellularly on cytokeratin intermediate filaments. Mol Pharmacol 2011; 79: 400-10.

20. Cheng SB, Graeber CT, Quinn JA, Filardo EJ. Retrograde transport of the transmembrane estrogen receptor, G-protein-coupled-receptor-30 (GPR30/GPER) from the plasma membrane towards the nucleus. Steroids 2011; 76: 892-6.

21. Otto C, Rohde-Schulz B, Schwarz G, et al. G protein-coupled receptor 30 localizes to the endoplasmic reticulum and is not activated by estradiol. Endocrinology 2008; 149: 4846-56.

22. Filardo EJ, Quinn JA, Bland KI, Frackelton Jr AR. Estrogen-induced activation of Erk-1 and Erk-2 requires the G-protein coupled receptor homolog, GPR30, and occurs via transactivation of the epidermal growth factor receptor through release of HB-EGF. Mol Endocrinol 2000; 14: 1649-60.

23. Maggiolini M, Vivacqua A, Fasanella G, et al. The G Protein-coupled receptor GPR30 mediates c-fos up-regulation by $17 \beta$-estradiol and phytoestrogens in breast cancer cells. J Biol Chem 2004; 279: 27008-16.

24. Prossnitz ER, Barton M. Signaling, physiological functions and clinical relevance of the $G$ protein-coupled estrogen receptor GPER. Prostaglandins Other Lipid Mediat 2009; 89: 89-97.

25. Li Y, Birnbaumer L, Teng CT. Regulation of ERRalpha gene expression by estrogen receptor agonists and antagonists in SKBR3 breast cancer cells: differential molecular mechanisms mediated by g protein-coupled receptor GPR30/GPER-1. Mol Endocrinol 2010; 24: 969-80.

26. Prenzel N, Zwick E, Daub H, Leserer M, Abraham R, Wallasch C, Ullrich A. EGF receptor transactivation by G-protein-coupled receptors requires metalloproteinase cleavage of proHB-EGF. Nature 1999; 402(6764): 884-8.

27. Kanter-Lewensohn L, Girnita L, Girnita A, et al. Tamoxifen-induced cell death in malignant melanoma cells: possible involvement of the insulin-like growth factor-1 (IGF-1) pathway. Mol Cell Endocrinol 2000; 165: 131-7.

28. Quinn JA, Graeber CT, Frackelton AR Jr, Kim M, Schwarzbauer JE, Filardo EJ. Coordinate regulation of estrogen-mediated fibronectin matrix assembly and epidermal growth factor receptor transactivation by the G protein-coupled receptor, GPR30. Mol Endocrinol 2009; 23: 1052-64. 
29. De Marco P, Bartella V, Vivacqua A, et al. Insulin-like growth factor-I regulates GPER expression and function in cancer cells. Oncogene 2012; 32: 678-88.

30. Kang L, Zhang X, Xie Y, Tu Y, Wang D, Liu Z, Wang ZY. Involvement of estrogen receptor variant ER-alpha36, not GPR30, in nongenomic estrogen signaling. Mol Endocrinol 2010; 24: 709-21.

31. Pike MC, Pearce CL, Wu AH. Prevention of cancers of the breast, endometrium and ovary. Oncogene 2004; 23: 6379-91.

32. Daryanani D, Plukker JT, De Hullu JA, Kuiper H, Nap RE, Hoekstra HJ. Pregnancy and early-stage melanoma. Cancer 2003; 97: 2248-53.

33. O'Meara AT, Cress R, Xing G, Danielsen B, Smith LH. Malignant melanoma in pregnancy. A population-based evaluation. Cancer 2005; 103: 1217-26.

34. Folkerd EJ, Dowsett M. Influence of sex hormones on cancer pro gression. J Clin Oncol 2010; 28: 4038-44.

35. Mac Neil SM, Eves P, Richardson B, Molife R, Lorigan P, Wagner M, Layton C, Morandini R, Ghanem G. Oestrogenic steroids and melanoma cell interaction with adjacent skin cells influence invasion of melanoma cells in vitro. Pigment Cell Res 2000; 13 Suppl 8: 68-72.

36. Dobos J, Tímár J, Bocsi J, Burián Z, Nagy K, Barna G, Peták I, Ladányi $A$. In vitro and in vivo antitumor effect of 2-methoxyestradiol on human melanoma. Int J Cancer 2004; 112: 771-6.

37. Regad T. Molecular and cellular pathogenesis of melanoma initiation and progression. Cell. Mol Life Sci 2013; 70: 4055-65.

38. Mohr P, Eggermont AMM, Hauschild A, Buzaid A. Staging of cuta neous melanoma. Ann Oncol 2009; 20 (Suppl 6): vi14-vi21.

39. Meier F, Will S, Ellwanger U, Schlagenhauff B, Schittek B, Rassner G, Garbe C. Metastatic pathways and time courses in the orderly pro gression of cutaneous melanoma. Br J Dermatol 2002; 147: 62-70.

40. Brenner S, Tamir E. Early detection of melanoma: the best strategy for a favorable prognosis. Clin Dermatol 2002; 20(3): 203-11.

41. Houghton AN, Polsky D. Focus on melanoma. Cancer Cell 2002; 2: 275-8.

42. MacKie RM, Hauschild A, Eggermont AM. Epidemiology of invasive cutaneous melanoma. Ann Oncol 2009; 20 (Suppl 6): vi1-vi7.

43. Leiter U, Meier F, Schittek B, Garbe C. The natural course of cutaneous melanoma. J Surg Oncol 2004; 86 (4): 172-8.

44. Ashley DJ. Sex differences in the incidence of tumours at various sites. Br J Cancer 1969; 23: 26-30.

45. Blois MS, Sagebiel RW, Abarbanel RM, Caldwell TM, Tuttle MS. Malignant melanoma of the skin. I. The association of tumor depth and type, and patient sex, age, and site with survival. Cancer 1983 52: 1330-41.

46. Rampen FH. Sex differences in survival from cutaneous melanoma. Int J Dermatol 1984; 23: 444-52.

47. Reintgen DS, Paull DE, Seigler HF, Cox EB, McCarty KS Jr. Sex related survival differences in instances of melanoma. Surg Gynecol Obstet 1984; 159: 367-72.

48. Stidham KR, Johnson JL, Seigler HF. Survival superiority of females with melanoma. A multivariate analysis of 6383 patients exploring the significance of gender in prognostic outcome. Arch Surg 1994; 129: 316-24.

49. Karakousis CP, Driscoll DL. Prognostic parameters in localised melanoma: gender versus anatomical location. Eur J Cancer 1995; 31A: 320-4.

50. Miller JG, Mac Neil S. Gender and cutaneous melanoma. Br J Dermatol 1997; 136: 657-65.

51. Kölmel KF, Kulle B, Lippold A, Seebacher C. Survival probabilities and hazard functions of malignant melanoma in Germany 1972 1996, an analysis of 10433 patients. Evolution of gender differences and malignancy. Eur J Cancer 2002; 38: 1388-94.

52. Hofmann MA, Coll SH, Küchler I, Kiecker F, Wurm R, Sterry W, Trefzer U. Prognostic factors and impact of treatment in melano ma brain metastases: better prognosis for women? Dermatology 2007; 215: 10-6.

53. Lasithiotakis K, Leiter U, Meier F, Eigentler T, Metzler G, Moehrle M Breuninger $\mathrm{H}$, Garbe $\mathrm{C}$. Age and gender are significant independent predictors of survival in primary cutaneous melanoma. Cancer 2008; 112: 1795-804.

54. O'Doherty CJ, Prescott RJ, White H, McIntyre M, Hunter JA. Sex differences in presentation of cutaneous malignant melanoma and in survival from stage I disease. Cancer 1986; 58: 788-92.
55. De Giorgi V, Gori A, Alfaioli B, Papi F, Grazzini M, Rossari S, Lotti T, Massi D. Influence of sex hormones on melanoma. J Clin Oncol 2011; 29: e94-e5.

56. Grill HJ, Benes P, Manz B, Schramm P, Morsches B, Korting GW Pollow K. Steroid hormone receptors in human melanoma. Arch Dermatol Res 1982; 272: 97-101.

57. Creagan ET, Ingle JN, Woods JE, Pritchard DJ, Jiang NS. Estrogen receptors in patients with malignant melanoma. Cancer 1980; 46: 1785-6.

58. Zhao C, Dahlman-Wright K, Gustafsson JA. Estrogen receptor beta: an overview and update. Nucl Recept Signal 2008; 6: e003.

59. Zhao C, Dahlman-Wright K, Gustafsson JA. Estrogen signaling via estrogen receptor $\beta$. J Biol Chem 2010; 28: 39575-9.

60. Schmidt AN, Nanney LB, Boyd AS, King LE Jr, Ellis DL. Oestrogen receptor-beta expression in melanocytic lesions. Exp Dermatol 2006; 15: 971-80

61. De Giorgi V, Mavilia C, Massi D, et al. Estrogen receptor expression in cutaneous melanoma a real-time reverse transcriptase - polymerase chain reaction and immunohistochemical study. Arch Dermatol 2009; 145: 30-6.

62. De Giorgi V, Gori A, Gandini S, et al. Estrogen receptor beta and melanoma. A comparative study. Br J Dermatol 2013; 168: 513-519.

63. Ohata C, Tadokoro T, Itami S. Expression of estrogen receptor beta in normal skin, melanocytic nevi and malignant melanomas. J Dermatol 2008; 35: 215-21.

64. Grin CM, Driscoll MS, Grant-Kels JM. The relationship of pregnancy, hormones, and melanoma. Semin Cutan Med Surg 1998; 17: 167-71.

65. Asendrych A, Deptała A. Hormonal replacement therapy in hormone-dependent cancers. Wspolczesna Onkol 2004; 8:81-85.

66. Nading MA, Nanney LB, Boyd AS, Ellis DL. Estrogen receptor $\beta$ expression in nevi during pregnancy. Exp Dermatol 2008; 17: 489-97.

67. Nading MA, Nanney LB, Ellis DL. Pregnancy and estrogen recep tor $\beta$ expression in a large congenital nevus. Arch Dermatol 2009; 145: 691-4.

68. Koomen ER, Joosse A, Herings RMC, Casparie MIK, Guchelaar HJ, Nijsten T. Does use of estrogens decrease the Breslow thickness of melanoma of the skin? Oral contraceptives and hormonal replacement therapy. Melanoma Res 2009; 19: 327-32.

69. Tang JY, Spaunhurst KM, Chlebowski RT, et al. Menopausal hormone therapy and risks of melanoma and nonmelanoma skin cancers: women's health initiative randomized trials. J Natl Cancer Inst 2011; 103: 1469-75.

70. De Braud F, Khayat D, Kroon BB, Valdagni R, Bruzzi P, Cascinelli N. Malignant melanoma. Crit Rev Oncol Hematol 2003; 47: 35-63.

71. Eggermont AM, Robert C. New drugs in melanoma: it's a whole new world. Eur J Cancer 2011; 47: 2150-7.

72. Spagnolo F, Queirolo P. Upcoming strategies for the treatment of metastatic melanoma. Arch Dermatol Res 2012; 304: 177-84.

73. Thumar J, Giesen E, Kluger HM. Drug targets and predictive biomarkers in the management of metastatic melanoma. Pharmgenomics Pers Med 2012; 5: 139-48.

74. Scheier B, Amaria R, Lewis K, Gonzalez R. Novel therapies in melanoma. Immunotherapy 2011; 3: 1461-9.

75. Mackiewicz J, Kwinta Ł. New targeted therapies in the treatment of patients with metastatic melanoma. Wspolczesna Onkol 2010; 14: $15-22$.

\section{Address for correspondence}

\section{Marcelina E Janik}

Gronostajowa 9

30-387 Krakow, Poland

e-mail: marcelina.janik@uj.edu.pl

Submitted: 8.08 .2013

Accepted: $\quad 16.10 .2013$ 